\title{
Afterlife Beliefs: An Evolutionary Perspective
}

\author{
Steve Stewart-Williams \\ School of Psychology, University of Nottingham Malaysia
}

\begin{abstract}
This article surveys and evaluates the main evolutionary explanations for a common feature of religions around the world: afterlife beliefs. It argues that the prototypical evolutionary explanation - the idea that the trait under discussion is an adaptation crafted by natural selection - is the least plausible in this case. Byproduct explanations and explanations based on cultural evolution are more promising. Furthermore, these approaches may work in tandem with one another. Specifically, the fact that humans are susceptible to afterlife beliefs may be a byproduct of aspects of our evolved nature that were selected for other purposes, but the particular afterlife beliefs found in a given culture may be a product of natural selection in the cultural realm (survival of the fittest ideas or memes).
\end{abstract}

KEYWORDS: Afterlife Beliefs; Cultural Evolution; Evolutionary Psychology; Memetics; Religion. 
Afterlife Beliefs

An Evolutionary Approach

If we were not afraid of death, I do not believe that the idea of immortality would ever have arisen.

Fear is the basis of religious dogma, as of so much else in human life.

-Bertrand Russell

We are all going to die and we all know it. We have our first glimmerings of this unpleasant fact in early childhood, and live with it for the rest of our lives. Sometimes it sits at the forefront of our attention; other times it lurks in the background - but it's always there somewhere, casting a dark shadow across our hopes for meaning and permanence.

From a zoological perspective, this is a rather peculiar situation to be in. As far as we know, no other species is aware of its own mortality. It would be strange if they were - but it's no less strange for us. Stranger still, though, is the fact that so many people, while fully cognizant of their own looming demise, believe that death is not the end.

Afterlife beliefs of one sort or another are a central feature of most of the world's religions. Early scholars of religion accorded this fact a central place in their thinking. The psychologist and philosopher William James (1902), for instance, argued that the wish for immortality is the ultimate wellspring of religious belief and practice (p. 412). Curiously, however, this topic has been largely neglected in recent scholarship on the psychology of religion. This paper explores an increasingly popular approach to explaining religious behavior - the Darwinian approach - and asks what light this approach might shed on the origins of our afterlife beliefs.

The most obvious hypothesis stemming from an evolutionary perspective is that the belief in life after death, and religiosity more generally, is an adaptation crafted by natural 
selection. However, this is only one among several possible hypotheses for the evolutionist, and is probably the least plausible in this case. A second hypothesis is that belief in an afterlife is an evolutionary byproduct or "spandrel" - that is, a side effect of other adaptations, rather than an adaptation in its own right (Atran, 2002; Boyer, 2001). The bellybutton is a good example of a byproduct; this trait was not specifically favored by natural selection, but is instead a functionless side-effect of another trait: the umbilical cord. Applying this framework to afterlife beliefs, the claim would be that, like the bellybutton, such beliefs are not adaptations but are byproducts of cognitive capacities that were selected for other purposes. Likely candidates include the fear of death and theory of mind.

A third and final Darwinian hypothesis involves applying evolutionary principles, not to genes or biology, but to the units of culture or memes (Boyd \& Richerson, 1985; Dawkins, 1976; Henrich, 2016; Sperber, 1996). One might argue, for instance, that afterlife beliefs were subject to a process analogous to natural selection, and that they survived and thrived in many of the world's cultures because they were good for the individuals holding them, good for their groups, or good simply at persisting in people's minds and motivating people to pass them on. In the following pages, I consider each of these possibilities in turn. To set the stage, however, I briefly survey the range and diversity of afterlife beliefs in the world today.

\section{A Survey of Afterlife Beliefs}

Afterlife beliefs come in a diverse array of forms (Moreman, 2008; Segal, 2004; Shushan, 2009). It is possible, however, to detect a number of broad themes in the afterlife beliefs of the world's religions. To begin with, a distinction can be drawn between those that involve personal survival and those that do not. Most fall into the former category; they posit survival of the individual as a distinct personality with at least some of the attributes of the living person. Personal survival beliefs can be divided in turn into two further kinds: those 
involving survival in a physical body (e.g., bodily resurrection on Judgment Day), and those involving survival as a disembodied mind or soul (e.g., the migration of the soul to an afterworld following bodily death). Reincarnation blends these visions: It posits post-mortem survival in a physical body, but also implies the transference of a nonphysical soul from one body to another.

Alongside afterlife beliefs involving individual survival are those that, while denying that consciousness is simply extinguished at death, assert that the individual does not persist in any recognizable sense. Examples include the notion that, with death, the barriers of the self dissolve and the individual merges back into a collective consciousness or Godhead.

Afterlife beliefs of one sort or another hold an important place in many people's lives. It is difficult to get good estimates of the rates of belief across the globe, because most surveys on the topic are conducted only in the West. What evidence is available, however, suggests that afterlife beliefs are most widely held in the Middle East and Africa, and least widely held in Western Europe and East Asia (Duffy, 2011). Among Western nations, the United States has the highest rate of professed belief in an afterlife. Typical estimates put the rates of belief among Americans at between 75\% and 90\% (Exline, 2003; Gallup, 2006; Murphy, 2015; Pond, Smith, \& Clement, 2010).

Although afterlife beliefs of one sort or another are of central importance in most major religious traditions today, this has not always been the case. In the religions of Ancient Greece and Israel, for instance, afterlife beliefs were less prominent and vaguer than their modern equivalents (Bremmer, 2002). Moreover, it is uncertain whether our hunter-gatherer ancestors had afterlife beliefs at all. On the one hand, some claim that such beliefs are largely absent in contemporary non-state societies, such as Hadza hunter-gatherers of Tanzania, the Nuer pastoralists of Sudan, and the Pirahã people of the Amazon basin (Everett, 2012; Norenzayan, 2013). On the other hand, we know that anatomically modern humans have been 
burying their dead for at least 100,000 years, often with elaborate ornaments such as shell beads (Mithen, 1996). Such activities seem to suggest a belief in life after death.

Regardless of when afterlife beliefs first appeared in the world, however, today they are ubiquitous. Where did they come from? In the remainder of the chapter, we will address this question using some of the standard tools of evolutionary biology. We begin with the most obvious evolutionary proposal: the idea that afterlife beliefs are a product of natural selection.

\section{Afterlife as Adaptation}

At first glance, the idea that the belief in life after death - or indeed any belief - is an adaptation might not look like a particularly promising line of inquiry. There have, however, been a number of efforts to flesh out the possible adaptive role of afterlife beliefs and of religious beliefs more generally. Most focus on the part these beliefs play in facilitating cooperation within the group. Applied to afterlife beliefs specifically, the suggestion would be that humans have an evolved predisposition to believe in life after death, and that this was selected because it provided either an advantage to individual group members (individual selection), or an advantage to the group as a whole (group selection).

\section{An Internal Big Brother}

One of the most important adaptationist explanations for afterlife beliefs comes from the evolutionary psychologist Jesse Bering (2006, 2010). Bering's claim is that human beings possess a cognitive system specifically dedicated to producing a range of religious convictions, among them, the belief that the mind is immortal and can exist independently of the body. A corollary of this belief is the idea that invisible agents - ancestors and gods, for instance - could be present and observing us at any given moment. Even atheists, Bering 
claims, have an intuitive sense that this is the case, despite the fact that they reject the possibility at an intellectual level.

The evolutionary payoff of this cognitive illusion, argues Bering, is that it motivates us to behave in a socially responsible manner, even when we might otherwise assume we could get away with bending the rules and cheating our friends and allies. This helps us to preserve a good reputation in the group, which in turn allows us to reap the rewards of group living and mutually beneficial cooperation. Of course, people have to learn the specific afterlife beliefs of their culture. But in Bering's view, our openness to such ideas is sewn into the very fabric of human nature. As he puts it, "the general idea of an afterlife is not so much implanted in people's heads by way of 'exposure' to counterintuitive tales, as it is already present" (Bering, 2002, p. 269).

Bering and his collaborators have assembled several lines of evidence to support this contention. This includes research showing that people primed with the idea of a supernatural watcher behave more honestly than those not, even when cheating is possible. In one study, children were brought into the lab to engage in a task. As the researchers briefed the children prior to the study, they mentioned - supposedly in passing - that an invisible girl called Princess Alice was in the room with them. As hypothesized, the children were later less likely than controls to cheat on the task after the experimenter left the room (Piazza, Bering, \& Ingram, 2011). The same effect was found in a study of young adults who were told, again supposedly in passing, that a ghost had been seen in the vicinity of the lab (Bering, McLeod, \& Shackelford, 2005).

Another line of research explored children's intuitions about the persistence of mental life after death. In one study, American children aged between four and twelve watched a puppet show in which an alligator ate a mouse. They were then asked whether the mouse still had bodily states (e.g., if it could see, or feel hunger or thirst), and whether it still had mental 
states (e.g., if it could know things, want things, or feel sad). In general, children were more likely to say that the mouse retained mental states than bodily ones (Bering \& Bjorklund, 2004). This was true regardless of age. Importantly, though, the younger the children were, the more likely they were to say the mouse would have some kind of psychological experience after death. This is revealing, because younger children have had less exposure than older ones to the religious beliefs of their community. Bering and Bjorklund (2004) conclude, therefore, that the belief in psychological continuance could not come from children's religious training. Instead, it is our default presumption - and if anything is learned, it is the idea that we are not immortal. The findings of the study were later replicated in Spain, at both a Catholic and a secular school, suggesting that the original results were not just a product of Anglo-American culture or religious schooling (Bering, Hernández Blasi, \& Bjorklund, 2005; see also Emmons \& Kelemen, 2014).

So, several lines of evidence lend credence to the idea that humans possess dedicated cognitive faculties for belief in psychological immortality. However, although the evidence is consistent with this conclusion, it does not compel it. Consider again the Princess Alice study. If, as Bering suggests, we have a built-in tendency to believe in invisible watchers, it is unclear why the researchers would need to prime the idea of an invisible watcher to get the effect. Conversely, given that they did prime this idea, it is unclear why we would need to posit a built-in tendency to believe in invisible watchers to explain the reduced cheating. A simpler explanation would be that, rather than participants behaving more honestly because of an innate sense that they were being watched, they behaved more honestly because the experimenters effectively told them they were being watched.

Next, consider the claim that younger children have stronger afterlife beliefs than older ones (and presumably also than adults), and therefore that these beliefs could not come from the surrounding culture. Again, the evidence does not force the conclusion. It seems 
perfectly plausible that adults teach young children afterlife beliefs that they themselves do not fully believe, and perfectly plausible that the children hold these beliefs more strongly than their teachers because the children's critical faculties are as yet less well developed. If so, children could acquire their afterlife beliefs from the culture around them, even though they hold them more strongly than the people who teach them the beliefs. On top of this theoretical difficulty, at least one study (Harris and Giménez, 2005) found that afterlife beliefs $d o$ in fact get stronger as children get older. At the very least, then, the evidence is ambiguous.

Finally, Bering's theory is difficult to reconcile with the fact that, in many tribal societies, supernatural agents take little interest in people's moral conduct. It is only with the growth of large-scale societies that gods and ancestors start rewarding good behavior and punishing bad (Norenzayan, 2013; Wright, 2009). And even if moralizing supernatural agents were ubiquitous, it is easy to imagine more direct ways that natural selection could reduce selfish, exploitative behavior. Specifically, selection could increase the average willingness of people to cooperate, and decrease their average willingness to cheat, rather than crafting a complex cognitive system dedicated to the production of a belief in disembodied watchers. The latter seems like an unnecessarily laborious way to achieve natural selection's metaphorical goal.

\section{Religion as a Costly Signal}

A second adaptationist explanation for religion comes from the evolutionary anthropologist William Irons (2001; see also Sosis, 2003). In Irons’ view, a central component of all religious systems is costly, hard-to-fake signals of commitment to the wider group. These signals, which include everything from tithing to upholding inconvenient dietary regulations, are a solution to the problem of free riders: people who enjoy the benefits 
of group membership, but who fail to reciprocate or who abandon the group as soon as the costs of membership outweigh the gains. Because free riders harm the group, successful groups must have mechanisms to weed them out wherever possible. Costly religious practices and rituals do exactly that. They demonstrate that the signaler is a genuine and committed believer and therefore is unlikely to exploit the group, even if the opportunity arises. Costly religious beliefs might serve the same end. Holding implausible beliefs about the world may function as an honest signal of commitment. As Sosis and Alcorta (2008) put it, "By incorporating counterintuitive concepts within belief systems, religion creates reliable costly signals that are difficult to "fake"' (p. 243).

Although no research has tested this idea directly, several studies have tested the more general claim that costly displays thwart free riders and promote group solidarity. In one such study, Richard Sosis and Eric Bressler (2003) compared religious communes in nineteenthcentury North America to socialist communes from the same period. The religious communities had stricter rules than their secular counterparts: never eat meat, never drink alcohol, never have sex. They also tended to persist for longer, consistent with the costlydisplay theory. Moreover, among the religious communes, the costlier the requirements of membership, the more durable the groups tended to be. These findings are broadly consistent with the idea that groups that make strong demands of their members have a reduced risk of exploitation by free riders.

At the same time, though, the costly display hypothesis faces a number of challenges and criticisms. First, it is far from clear that holding implausible beliefs would actually work as a hard-to-fake signal; on the face of it, the signal would seem relatively easy to fake. Furthermore, even if groups insisting on costly religious displays do tend to be more successful, it remains an open question whether this is a direct product of natural selection. Sosis (2003) himself is agnostic about whether the tendency is an adaptation or a byproduct, 
and perhaps this is a sensible position. After all, religious signaling may be just a specific instance of a more general evolved tendency to display and insist on costly signals. Alternatively, it might be a product of cultural evolution. Either way, the evidence available at present does not uniquely lend itself to an adaptationist interpretation.

\section{General Evaluation of Adaptationist Approaches}

In addition to the difficulties associated with specific adaptationist explanations of afterlife beliefs, a number of arguments can be raised against any adaptationist explanation. First and foremost, not all individuals and not all groups hold afterlife beliefs. As Banerjee and Bloom (2013) point out, this makes these beliefs very different from less controversial psychological adaptations, such as the capacity for language (see Pinker \& Bloom, 1992). All normal children readily acquire a language, and anthropologists have yet to find a human culture without one. This is not the case for afterlife beliefs, which weakens any adaptationist argument.

Furthermore, it seems unlikely that specific afterlife beliefs - heaven and hell, resurrection and reincarnation - are directly innate. If anything is innate, it is presumably a general openness to religious beliefs or perhaps a tendency to conform to local norms and practices - what Richerson and Boyd (1985) call the conformist bias. In either case, though, this would not be an adaptationist account of afterlife beliefs specifically. Afterlife beliefs would just be an offshoot of a more general adaptation - namely, religiosity or conformity. In other words, we would be dealing with a byproduct account rather than an adaptationist one. It is to the byproduct approach that we now turn. 
Afterlife as Byproduct

Arguably, the most popular approach to religious beliefs among evolution-minded scholars today is the byproduct or spandrel approach. Applied to afterlife beliefs, the hypothesis would be that belief in post-mortem survival is not itself an adaptation, but instead is a side effect of other traits that are. Which traits might these be? In this section, I survey some of the main contenders.

\section{Death Anxiety}

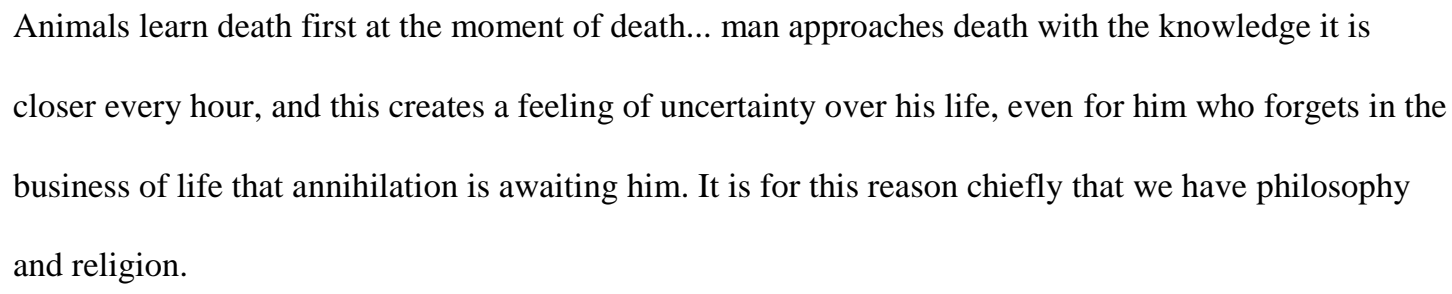

-Arthur Schopenhauer

The most widely touted byproduct explanation for afterlife beliefs has its roots in one of the best-known theories of religion: the idea that religious beliefs are products of wishful thinking. More precisely, afterlife beliefs are a response to our natural dread of death and extinction (Jonas \& Fischer, 2006). This dread is itself a byproduct of the sophisticated cognitive capacity that enable our species, uniquely among the animals, to understand that one day, probably sooner than we hope, we will die. Afterlife beliefs are a cultural antidote to this anxiety-inducing insight - a byproduct of a byproduct.

The wishful thinking approach has a long and distinguished history in psychology. Sigmund Freud (1928), for instance, wrote that: 
We shall tell ourselves that it would be very nice if there were a God who created the world and was a benevolent providence, and if there were a moral order in the universe and an afterlife; but it is a very striking fact that all this is exactly as we are bound to wish it to be. And it would be more remarkable still if our wretched, ignorant and downtrodden ancestors had succeeded in solving all these difficult riddles of the universe. (p. 42)

More recently, the wishful-thinking baton has been taken up by Terror Management Theory (TMT; Vail et al., 2010). According to TMT, death anxiety is one of the deepest psychological forces shaping our cultures and institutions. Our efforts to suppress or subdue the fear of death underpin many central aspects of human life, religion among them. From this perspective, afterlife beliefs are one among a variety of ways in which people dampen the terror associated with an awareness of their impending extinction and the sense of ultimate futility that this engenders. Advocates of TMT explicitly acknowledge that this is an evolutionary byproduct theory: Death anxiety is, on their view, a byproduct of human intelligence, and so, therefore, is the belief in an afterlife. When pressed, they concede that the reduction of death anxiety is not the only function of religious beliefs; there are others as well, such as boosting group cohesion. Nonetheless, reducing anxiety is their primary function.

Several lines of evidence are concordant with this view. These include surveys showing that belief in an afterlife is negatively correlated with death anxiety (e.g., Harding, Flannelly, Weaver, \& Costa, 2005), and laboratory studies suggesting that, for theists and agnostics alike, death reminders can ratchet up people's faith in both God and an afterlife (Vail, Arndt, \& Abdollahi, 2012; Vail et al., 2010).

Not all the research points in this direction, however. First, some studies fail to find any relationship between belief in an afterlife and death anxiety (e.g., Bering, 2002). Second, 
people's conviction that there is an afterlife does not seem to increase with age, despite everincreasing proximity to death (Harley \& Firebaugh, 1993). Third, and perhaps most decisively, even a cursory look at the afterlife beliefs of the world's religions reveals that many are anything but comforting [citation redacted]. Most obviously, the notion of hell is a profoundly terrifying doctrine (Bernstein, 1993; Camporesi, 1987/1990). As the anthropologist A. R. Radcliffe-Brown (1952) noted, rather than alleviating people's fears, afterlife beliefs may saddle believers with "fears and anxieties from which they would otherwise be free" (p. 149). The implication is clear: Although the alleviation of death anxiety undoubtedly helps to explain the popularity of some afterlife beliefs, it could not be the complete explanation. We need to explore other avenues.

\section{Theory of Mind and Intuitive Dualism}

One promising avenue draws on the concept of theory of mind. Theory of mind is the capacity to construe other individuals as agents possessing mental states such as thoughts, beliefs, perceptions, feelings, and desires (Leslie, 1994). Although a handful of nonhuman species seem to have the rudiments of this cognitive talent (Call \& Tomasello, 2008; Premack \& Woodruff, 1978), theory of mind appears to be largely unique to humans, and plausibly has an evolutionary origin (Baron-Cohen, 1999; citation redacted). Most likely, it evolved as a way for us to predict and influence other people's behaviour. With theory of mind added to our species' mental toolkit, humans came to represent the world using two distinct cognitive "vocabularies": a physical one, which construes the world in terms of objects interacting in three-dimensional space, and a psychological one, which explains events in terms of agency and invisible mental states.

Theory of mind sets the stage for the appearance of afterlife beliefs. The fact that we construe physical and mental "entities" in such different ways makes it easy for us to imagine 
that mind and brain are separate - and potentially separable - entities. To use Bloom's (2004) phrase, it turns us into intuitive dualists. Our intuitive dualism, in turn, makes it easy for us to believe that the mind can potentially survive the death of the body. It certainly doesn't force this conclusion; all normal human beings possess theory of mind but not all believe in independently existing, immortal souls. Nonetheless, the belief does come easily to us, because it coheres well with the innate architecture of the human mind. If we had not evolved the capacity for theory of mind, then we - like every other animal - would lack the capacity to entertain afterlife beliefs. In that sense, afterlife beliefs are a byproduct of theory of mind.

\section{Simulation Constraints}

Not only is it easy to imagine that the mind continues to exist after death, it may be difficult to imagine otherwise. According to Bering (2002), the human mind is constitutionally unable to imagine nonexistence, and this intellectual blind spot biases us toward belief in the continued existence of the mind. Bering's hypothesis is a scientific elaboration of an idea that has been floating around for several centuries. Goethe, for instance, observed that "It is quite impossible for a thinking being to imagine nonbeing, a cessation of thought and life," and Freud suggested that "Our own death is indeed unimaginable, and whenever we make the attempt to imagine it we can perceive that we really survive as spectators... at bottom no one believes in his own death" (quoted in Nichols, 2007, p. 215, 218). It was Bering, however, who first brought the idea into the realm of testable science.

Note that, although the simulation constraints theory is readily interpreted as a byproduct explanation of afterlife beliefs, one could equally well argue that these constraints are a specific adaptation - something that was selected because of its effects in promoting these very beliefs. Indeed, this is the line that Bering has taken. Given the difficulties 
associated with the notion that afterlife beliefs are directly innate, however, the byproduct approach would appear to be more plausible.

As plausible as it might seem, however, the simulation constraints hypothesis faces a number of objections. It is true, of course, that we cannot visualize what it would be like not to exist, for the simple reason that it would not be like anything. It is not so obvious, however, that we have much trouble comprehending the idea at a more abstract level. After all, though we cannot visualize our own nonexistence before birth, we do not find the idea that we did exist at that time particularly compelling - not unless we were raised with this belief. Furthermore, the alleged impossibility of visualizing nonexistence has not spared people from existential horror at the notion of eternal nonexistence. Nonetheless, for anyone torn between belief in continued existence and outright extinction, the relative difficulty of imagining the latter may, in some cases, function as a tiebreaker.

\section{General Evaluation of the Byproduct Account}

Those, then, are the main byproduct explanations for the belief in life after death. Importantly, these explanations are not mutually exclusive. For example, the fact that a belief in psychological immortality comes relatively easily to people makes it a suitable tool for other tasks, including reducing death anxiety. This, coupled with the fact that afterlife beliefs are not readily disconfirmed in everyday life, may jointly explain why these ideas are so persistent and successful.

Still, the byproduct approach can only take us so far. It helps to explain our general proneness to afterlife beliefs, but not the fact that people hold the particular afterlife beliefs they do, or the fact that these beliefs vary across cultures and have changed and diversified over time. To explain these things, we need to factor in the historical development of these 
quintessentially human beliefs. We need, in other words, to consider the cultural evolution of the afterlife.

\section{Afterlife as Cultural Adaptation}

Cultural evolutionary theory is a growing approach to understanding the human mind and human culture (Boyd \& Richerson, 1985; Dawkins, 1976; Henrich, 2016; Mesoudi, 2011; citation redacted). There are several distinct schools of thought under this umbrella, but all have in common the assumption that Darwinian principles can shed light on the origins and nature of culture. Most also include the idea that culture is shaped, at least in part, by natural selection. To be clear, the suggestion is not that selection shapes culture by acting on genes. The suggestion is that selection shapes culture by acting on culture itself.

Among the main ideas about how this might work are: (1) that cultural elements are selected to the extent that they enhance their bearer's genetic fitness (the adaptive-culture hypothesis); (2) that cultural elements are selected to the extent that they are good for the group (cultural group selection); and (3) that cultural elements are selected to the extent that they are good for themselves - in other words, to the extent that they have properties that cause them to stick in people's minds and spread through the culture (memetics). A further suggestion is that culture creates new selection pressures, which lead to biological evolution (gene-culture coevolution). As with the different byproduct explanations, these propositions are not mutually exclusive, and each has potential implications for the scientific understanding of afterlife beliefs.

\section{Adaptive Culture}

The first hypothesis, which I call the adaptive-culture hypothesis, is based on the assumption that culture tends to enhance genetic fitness. This is not an unreasonable 
assumption; after all, if culture did not enhance fitness, at least on average, the capacity for culture would likely never have evolved. According to various scholars, humans possess a range of sophisticated learning biases, which dispose us to acquire fitness-enhancing ideas and behavior patterns. This includes a tendency to adopt the ideas and practices of successful, high-status individuals (the prestige bias) and a tendency to adopt the ideas and practices that are most common in the group (the conformist bias, mentioned earlier; Boyd \& Richerson, 1985; Henrich \& McElreath, 2003). In both cases, these ideas and practices have a betterthan-average chance of being adaptive. As such, any bias toward adopting them would itself be adaptive. These learning biases would in turn help channel the evolution of culture in adaptive directions.

The adaptive-culture approach provides a novel way to explain adaptive religious ideas and practices. Rather than being biological adaptations, they are cultural inventions but cultural inventions shaped by a mind designed to produce and favor fitness-enhancing culture. They are thus adaptive without being adaptations per se. To put it another way, they are acquired adaptations [citation redacted].

If accurate, the adaptive-culture hypothesis allows us to take the explanatory logic proposed by adaptationist accounts of religion and reconstitute it in terms of cultural selection. Consider, for instance, Bering's suggestion that belief in an afterlife is adaptive because it tends to dissuade people from cheating allies and group members. For the reasons outlined earlier, it seems unlikely that this is a biological adaptation. However, Bering's adaptationist explanation may nonetheless be correct, except with the proviso that the adaptive design comes from cultural rather than biological evolution. 


\section{Cultural Group Selection}

There must be more to the story, though, for cultural products do not always enhance individual fitness. According to proponents of cultural group selection theory, many core aspects of human culture - religion included - emerge from competition between groups and thus are designed to enhance the fitness not of the individual but of the group as a whole (Henrich, 2004; Richerson et al., 2015; Wilson, 2002).

The process works as follows. Different groups have different beliefs, norms, practices, tools, and technology. As a result of these differences, some groups do better than their neighbors: They outcompete them, grow at a faster rate, or defeat them in direct competition. In the process, the cultural elements that helped secure the group's success come to predominate within the meta-population of groups. In this way, according to cultural group selection theory, cultural practices evolve to benefit the group, without necessarily benefiting the individuals holding them. A crucial part of this hypothesis is the idea that no one needs to deliberately design these practices with this end in mind. Cultural group selection may simply favor practices that benefit the group, even in ways that group members do not notice or understand [citation redacted].

Several thinkers have applied cultural group selection to the question of afterlife beliefs. In his book Darwin's Cathedral, David Sloan Wilson (2002) proposed that afterlife beliefs were selected because they enhanced the solidarity of the groups holding them, increasing their ability to compete with other groups. In a similar vein, Ara Norenzayan (2013) argued that the major religious traditions of the world evolved to foster cooperation in large-scale societies. For groups of 100 to 250 people - the kinds of groups in which we spent most of our evolutionary history - our evolved social instincts are sufficient to maintain order and cooperation (see, e.g., Dunbar, 1993). As societies grow larger, however, our instincts start to fall short, and some kind of cultural support is necessary. According to Norenzayan, 
the major religions of the world provide just such support. ${ }^{1}$ Afterlife beliefs may be an important part of this.

Several lines of evidence support the cultural group selectionists' approach. First, the approach makes good sense of the observation that, in early civilizations and pre-state societies, afterlife beliefs were relatively unimportant, if not entirely absent. The suggestion would be that, until we started living together in large groups, these beliefs were not needed and thus were not favored by cultural group selection. Second, there is evidence that afterlife beliefs do indeed foster group cohesion. Cross-national surveys, for example, indicate that afterlife beliefs are associated with higher levels of cooperation, just as cultural group selection theory would predict (Atkinson \& Bourrat, 2011).

Certainly, in modern Western nations, cooperation is common and social cohesion high, despite the fact that afterlife beliefs are far from ubiquitous. According to Norenzayan, however, this is because these nations have developed alternative, nonreligious tactics for keeping the peace, including secular ethical systems, police, and CCTV cameras. Religions are one form of social glue; they are not the only form.

\section{Memetics}

A radically different approach traces back to Richard Dawkins' 1976 book, The Selfish Gene (see also Blackmore, 1999; Dennett, 2006). The approach is called memetics, and the central idea is that cultural elements - which Dawkins dubbed memes - can, in some respects, be viewed as analogous to genes. Just as selection in the biological realm favors

\footnotetext{
${ }^{1}$ Note that there is some debate about the direction of causality here: Did the emergence of large-scale societies give rise to religion, or did religion come first and make possible the emergence of large-scale societies? See Watts et al. (2015).
} 
genes that help promote their own continuance in the gene pool, so too selection in the cultural realm favors memes that help promote their own continuance in the culture. The memes that do best are not necessarily those that are good for the individual or good for the group as a whole; instead, they are those that are good for themselves - those, in other words, that are best at sticking in people's minds and motivating people to pass them on, regardless of whether they help or harm their carriers or their carriers' groups in the process.

As argued elsewhere (citations redacted), the best way to construe memetics is not as an alternative to cultural group selection or the adaptive-culture hypothesis, but rather as an overarching framework that incorporates these approaches but also goes beyond them. Although memes are ultimately selected because they benefit themselves, they often do so by benefiting the people possessing them or the groups in which they are found. To put it another way, the adaptive-culture hypothesis and cultural group selection are special cases of a deeper truth: namely, that memes prosper to the extent that they facilitate their own replication.

At first glance, it might seem that Dawkins' theory does little work; it simply organizes other theories of afterlife beliefs under the banner of the word "meme." But this is to sell the approach short. The unique claim of memetics is that, in the final analysis, memes are selected to the extent that they benefit themselves. As such, memetics alone can explain instances where a meme is successful despite being bad for the individual or bad for the group hosting it.

Arguably, some religious beliefs, including some afterlife beliefs, meet this description. Consider the notion that it is a great and noble thing to become a martyr for one's religion, and that martyrs secure an eternal reward in a perfect afterworld (Sosis \& Alcorta, 2008). Assume for the sake of argument that one in a thousand people who hold this belief end up martyring themselves. At first, it might seem that such a meme would never be 
favored; after all, it kills a certain fraction of those who hold it, and when it does, the meme goes to the grave with its martyred host. But add to the equation the fact that, when someone takes the martyr's path, the story is often widely publicized, the martyr idolized, and the martyr's family rewarded. These effects may increase the appeal of the martyrdom meme to a certain segment of the population. As long as the meme creates at least as many converts for itself as it kills off, it could sustain and even spread itself, despite being bad for its hosts or bad for the group as a whole.

Of course, memes do not exist in a vacuum. Just as organisms evolve and adapt to their environment, so memes evolve and adapt to theirs: the environment constituted by the human mind and the local culture. Successful memes must "push our buttons" in ways that make the memes stick in our minds and motivate us to pass them on to others. Afterlife beliefs do this in a number of ways [citation redacted]. First, they allay our natural fear of death and our misery at the death of our loved ones. In this respect, the meme approach overlaps with and embraces TMT. Second, afterlife beliefs may help us to manipulate other people's behaviour. The obvious example is that we use the promise of heaven and the threat of hell as carrot and stick, respectively (Sosis \& Alcorta, 2008). Third, ideas about the separability of mind and body, and the continued existence of the mind or soul following death, may give the impression of solving certain existential quandaries, including - for our pre-scientific forebears, at least - the question of what happens to us when we dream and how it is that we sometimes seem to encounter the dead in our dreams (cf. Tylor, 1871).

The meme approach also suggests a way to understand the historical development of afterlife beliefs. As already noted, the afterlife beliefs of the early civilizations were rather pallid and uninspiring compared with later elaborations. The Mesopotamians' netherworld, the Ancient Hebrews' Sheol, and the Ancient Greeks' underworld, for instance, were desolate places, with little to recommend them. In contrast, later-emerging religious traditions 
incorporated striking and vivid afterworld beliefs, from the eternal bliss of paradise to the everlasting torments of hell - beliefs that are still widely held today.

How did we get from there to here? The memetic approach suggests an answer. Afterlife memes, like many widespread memes, have been subject to intense selection over many thousands of years. The ones that remain with us are the survivors of a memetic arms race spanning millennia. At each step along the way, more vivid afterlife conceptions were selected over less vivid ones, not necessarily because they were better for us or our groups, but simply because they grabbed our attention more forcefully and impelled us to pass them on. Slowly but surely, our desirable post-mortem destinations became more and more enticing while our undesirable ones became more and more unpleasant [citation redacted].

Needless to say, recent cultural currents have changed the landscape substantially. For example, in many Christian denominations, the notion of hell has been progressively deemphasized or reinterpreted over the last century. Nonetheless, it is plausible to suppose that afterlife beliefs, wherever they are found, are a product of competition among the various options available.

Although memetics offers a promising, integrative approach to the cultural evolution of afterlife beliefs, the perspective also faces a number of criticisms. Perhaps the most important is the observation that memetics has not yet yielded much empirical fruit. In defense of the approach, however, it does stress something that other approaches do not namely, that memes can be selected even when they are not useful to us or our groups. Until and unless this possibly is ruled out, not only memetics but every approach to cultural evolution that does not make this claim must be considered uncertain. 


\section{Gene-Culture Coevolution}

The final approach to consider is gene-culture coevolutionary theory (Durham, 1991; Lumsden \& Wilson, 1981; Richerson, Boyd, \& Henrich, 2010). The key idea here is that culture gives rise to new selection pressures, which then lead to biological change. This biological change may, in turn, give rise to new culture, which again creates new selection pressures and further biological change. Culture and biology evolve in lockstep with one another.

The classic example of gene-culture coevolution is lactose tolerance (Simoons, 1969). Most mammals are lactose intolerant from around the time of weaning. This includes most human beings. Indeed, until recently in our history, all adult humans were lactose intolerant. In the last six thousand years, however, people in various parts of the world started herding cattle. Suddenly, they had a new source of protein available to them: the milk of these nonhuman mammals. As soon as they started to avail themselves of this food source, they created a new selection pressure for the capacity to digest lactose throughout the lifespan. People possessing this capacity obtained more nutriment from their milk and thus had greater survival and reproductive success. In just a few thousand years, lactose tolerance was the norm in several populations: those with a long history of dairying. It is most common today among Northern Europeans, but is widespread throughout Western Eurasia, the Arabian peninsula, and parts of East Africa (Tishkoff et al., 2007).

Although lactose tolerance is the best-known example of a trait shaped by geneculture coevolution, there are various others. These include the ability to digest starch in populations with a high-starch diet (Perry et al., 2007) and a range of uniquely human activities such as throwing projectiles and crafting complex tools (Henrich, 2016).

Applied to religious beliefs, the gene-culture coevolutionary story might run as follows (see, e.g., Haidt, 2012; Wilson, 2002). Religion began life as a purely cultural 
phenomenon. As soon as it got a firm foothold in the community, however, it became so useful for its practitioners that natural selection favored any genetically mediated tendency toward religious belief or practice. In this way, religiosity may have started as an entirely learned trait but slowly became less dependent on learning and more on innate factors. In other words, religion may have morphed from a cultural phenomenon into an adaptation. More precisely, it may now sit somewhere in the no-man's land between these two categories - somewhere between adaptation and byproduct [citation redacted].

How likely is this? On the one hand, Haidt (2012) argues that religion has been with us for 50,000 years, and that this allows more than enough time for selection to have an impact. On the other hand, "religion" is such a broad term that it might be unrealistic to view it as a single, stable selection pressure. Unlike lactose, religious traditions are extremely variable and in a constant state of flux. It is doubtful, therefore, that the plodding hand of natural selection could get a tight enough grip on religion to start wiring a religious instinct into the human genome.

At this stage, the idea that religiosity - let alone specific religious beliefs - are a product of gene-culture coevolution is highly speculative. It is an interesting speculation, however, and one that might profitably be explored in future research on the psychology of religion.

\section{Conclusion}

To summarize, then, evolutionary theory provides a rich set of tools for tackling the question of afterlife beliefs. The prototypical evolutionary explanation - the adaptationist one - is probably the least plausible. Byproduct explanations and explanations based on cultural evolution seem more promising. Furthermore, these latter approaches may work in tandem with one another. Specifically, the fact that humans are susceptible to afterlife beliefs may be 
a byproduct of aspects of our evolved nature that were selected for other purposes, while the particular afterlife beliefs found in a given culture may be a product of selection among competing memes.

We cannot escape the knowledge that, one day, we will die. However, as the study of religion progresses, we may find ourselves approaching an understanding of why so many of us continue to believe that death is not the end. 


\section{References}

Atkinson, Q. D., \& Bourrat, P. (2011). Beliefs about God, the afterlife and morality support the role of supernatural policing in human cooperation. Evolution and Human Behavior, 32, 41-49.

Atran, S. (2002). In Gods we trust: The evolutionary landscape of religion. Oxford University Press.

Banerjee, K., \& Bloom, P. (2013). Would Tarzan believe in God? Conditions for the emergence of religious belief. Trends in Cognitive Sciences, 17, 7-8.

Baron-Cohen, S. (1999). The evolution of theory of mind. In M. C. Corballis \& S. E. G. Lea (Eds.), The descent of the mind: Psychological perspectives on hominid evolution (pp. 261-277). Oxford, England: Oxford University Press.

Bering, J. M. (2002). Intuitive conceptions of dead agents' minds: The natural foundations of afterlife beliefs as phenomenological boundary. Journal of Cognition and Culture, 2, 263-308.

Bering, J. M. (2006). The folk psychology of souls. Behavioral and Brain Sciences, 29, 453462.

Bering, J. M. (2010). The God instinct: The psychology of souls, destiny and the meaning of life. London, England: Nicholas Brealey.

Bering, J. M., \& Bjorklund, D. F. (2004). The natural emergence of reasoning about the afterlife as a developmental regularity. Developmental Psychology, 40, 217-233.

Bering, J. M., Hernández Blasi, C., \& Bjorklund, D. F. (2005). The development of afterlife beliefs in religiously and secularly schooled children. British Journal of Developmental Psychology, 23, 587-607.

Bering, J. M., McLeod, K., \& Shackelford, T. K. (2005). Reasoning about dead agents reveals possible adaptive trends. Human Nature, 16, 360-381.

Bernstein, A. E. (1993).The formation of hell: Death and retribution in the ancient and early Chrtstian worlds. Ithaca, NY: Cornell University Press.

Blackmore, S. (1999). The meme machine. Oxford, England: Oxford University Press.

Bloom, P. (2004). Descartes' baby: How the science of child development explains what makes us human. New York, NY: Basic Books.

Boyd, R., \& Richerson, P. J. (1985). Culture and the evolutionary process. Chicago, IL: University of Chicago Press.

Boyer, P. (2001). Religion explained: The evolutionary origins of religious thought. New York, NY: Basic Books.

Bremmer, J. N. (2002). The rise and fall of the afterlife. London, England: Routledge.

Call, J., \& Tomasello, M. (2008). Does the chimpanzee have a theory of mind? 30 years later. Trends in Cognitive Sciences, 12, 187-192.

Camporesi, ,P. (1991). The fear of hell: Images of damnation and salvation in early modern Europe (L. Byatt, Trans.). College Park, PA: Pennsylvania State University Press. (Original Italian edition 1987)

Dawkins, R. (1976). The selfish gene. Oxford, England: Oxford University Press.

Dennett, D. C. (2006). Breaking the spell: Religion as a natural phenomenon. New York, NY: Viking.

Duffy, B. (2011). Supreme being(s), the afterlife and evolution. ipsos.com. Retrieved 18 December, 2015, from http://www.ipsos-na.com/newspolls/pressrelease . aspx $? \mathrm{id}=5217$

Dunbar, R. I. M. (1993). Coevolution of neocortical size, group size, and language in humans. Behavioral and Brain Sciences, 16, 681-735. 
Durham, W. H. (1991). Coevolution: Genes, culture, and human diversity. Stanford, CA: Stanford University Press.

Emmons, N. A., \& Kelemen, D. (2014). The development of children's prelife reasoning: Evidence from two cultures. Child Development, 85, 1617-1633.

Everett, D. L. (2012). Language: The cultural tool. New York, NY: Vintage.

Exline, J. J. (2003). Belief in heaven and hell among Christians in the United States: Denominational differences and clinical implications. OMEGA - Journal of Death and Dying, 47, 155-168.

Freud, S. (1928). The future of an illusion. New York, NY: Norton.

Gallup. (2006). Religion. Gallup.com. Retrieved 18 December, 2015, from http://www.gallup.com/poll/1690/Religion.aspx

Haidt, J. (2012). The righteous mind: Why good people are divided by politics and religion. New York, NY: Random House.

Harding, S. R., Flannelly, K. J., Weaver, A. J., \& Costa, K. G. (2005). The influence of religion on death anxiety and death acceptance. Mental Health, Religion and Culture, $8,253-261$.

Harley, B., \& Firebaugh, G. (1993). Americans' belief in an afterlife: Trends over the past two decades. Journal for the Scientific Study of Religion, 32, 269-278.

Harris, P., \& Giménez, M. (2005). Children's acceptance of conflicting testimony: The case of death. Journal of Cognition and Culture, 5, 143-164.

Henrich, J. (2004). Cultural group selection, coevolutionary processes and large-scale cooperation. Journal of Economic Behaviour and Organisation, 53, 3-35.

Henrich, J. (2016). The secret of our success: How culture is driving human evolution, domesticating our species, and making us smarter. Princeton, NJ: Princeton University Press.

Henrich, J., \& McElreath, R. (2003). The evolution of cultural evolution. Evolutionary Anthropology, 12, 123-135.

Irons, W. (2001). Religion as a hard-to-fake sign of commitment. In R. M. Nesse (Ed.), Evolution and the capacity for commitment (pp. 292-309). New York, NY: Russell Sage.

James, W. (1902). The varieties of religious experience: A study in human nature. Harvard, MA: Harvard University Press.

Jonas, E., \& Fischer, P. (2006). Terror management and religion: Evidence that intrinsic religiousness mitigates worldview defense following mortality salience. Journal of Personality and Social Psychology, 91, 553-567.

Leslie, A., M. (1994). ToMM, ToBy, and Agency: Core architecture and domain specificity. In L. A. Hirschfeld \& S. A. Gelman (Eds.), Mapping the mind: Domain specificity in cognition and culture (pp. 119-148). New York, NY: Cambridge University Press.

Lumsden, C. J., \& Wilson, E. O. (1981). Genes, mind, and behavior: The coevolutionary process. Cambridge, MA: Harvard University Press.

Mesoudi, A. (2011). Cultural evolution: How Darwinian theory can explain human culture and unify the social sciences. Chicago, IL: University of Chicago Press.

Mithen, S. J. (1996). The prehistory of the mind: The cognitive origins of art, religion, and science. London, England: Thames \& Hudson.

Moreman, C. M. (2008). Beyond the threshold: Afterlife beliefs and experiences in world religions. Lanham, MD: Rowman \& Littlefield.

Murphy, C. (2015). Most Americans believe in heaven ... and hell. Retrieved 3 19, 2016 from Pew Research Center: http://www.pewresearch.org/fact-tank/2015/11/10/mostamericans-believe-in-heaven-and-hell/ 
Norenzayan, A. (2013). Big gods: How religion transformed cooperation and conflict. Princeton, NJ: Princeton University Press.

Perry, G. H., Dominy, N. J., Claw, K. G., Lee, A. S., Fiegler, H., Redon, R., . . Stone, A. C. (2007). Diet and the evolution of human amylase gene copy number variation. Nature Genetics, 39, 1256-1260.Piazza, J., Bering, J. M., \& Ingram, G. (2011). "Princess Alice is watching you": Children's belief in an invisible person inhibits cheating. Journal of Experimental Child Psychology, 109, 311-320.

Pinker, S., \& Bloom, P. (1992). Natural language and natural selection. In J. Barkow, H. L. Cosmides \& J. Tooby (Eds.), The adapted mind: Evolutionary psychology and the generation of culture (pp. 451-493). Oxford, England: Oxford University Press.

Pond, A., Smith, G., \& Clement, S. (2010). Religion among the millennials: Less religiously active than older Americans, but fairly traditional in other ways. Washington, DC: Pew Research Center.

Premack, D., \& Woodruff, G. (1978). Does the chimpanzee have a theory of mind? Behavioral \& Brain Sciences, 1, 515-526.

Radcliffe-Brown, A. R. (1952). Structure and function in primitive society: Essays and addresses. New York, NY: Free Press.

Richerson, P. J., Baldini, R., Bell, A., Demps, K., Frost, K., Hillis, V., . . Zefferman, M. (2015). Cultural group selection plays an essential role in explaining human cooperation: A sketch of the evidence. Behavioral and Brain Sciences, 39, e30.

Richerson, P. J., Boyd, R., \& Henrich, J. (2010). Gene-culture coevolution in the age of genomics. Proceedings of the National Academy of Sciences, 7, 8985-8992.

Segal, A. F. (2004). Life after death: A history of the afterlife in the religions of the west. New York, NY: Doubleday.

Shushan, G. (2009). Conceptions of the afterlife in early civilization: Universalism, constructivism and near-death experience. London, England: Continuum.

Simoons, F. J. (1969). Primary adult lactose intolerance and the milking habit: A problem in biological and cultural interrelations. The American Journal of Digestive Diseases, $14,819-836$.

Sosis, R. (2003). Why aren't we all Hutterites? Costly signaling theory and religious behavior. Human Nature, 14, 91-127.

Sosis, R., \& Alcorta, C. (2008). Militants and martyrs: Evolutionary perspectives on religion and terrorism. In R. Sagarin \& T. Taylor (Eds.), Natural security: A Darwinian approach to a dangerous world (pp. 105-124). Berkeley, CA: University of California Press.

Sosis, R., \& Bressler, E. R. (2003). Cooperation and commune longevity: A test of the costly signaling theory of religion. Cross-Cultural Research, 37, 211-239.

Sperber, D. (1996). Explaining culture: A naturalistic approach. Oxford: Blackwell.

Tishkoff, S. A., Reed, F. A., Ranciaro, A., Voight, B. F., Babbitt, C. C., Silverman, J. S., . . . Deloukas, P. (2007). Convergent adaptation of human lactase persistence in Africa and Europe. Nature Genetics, 39, 31-40.

Tylor, E. B. (1871). Primitive culture: Researches into the development of mythology, philosophy, religion, art and customs. New York, NY: Henry Holt.

Vail, K. E., Arndt, J., \& Abdollahi, A. (2012). Exploring the existential function of religion and supernatural agent beliefs among Christians, Muslims, atheists, and agnostics. Personality and Social Psychology Bulletin, 38, 1288-1300.

Vail, K. E., Rothschild, Z. K., Weise, D. R., Solomon, S., Pyszczynski, T., \& Greenberg, J. (2010). A terror management analysis of the psychological functions of religion. Personality and Social Psychology Review, 14, 84-94. 
Watts, J., Greenhill, S. J., Atkinson, Q. D., Currie, T. E., Bulbulia, J., \& Gray, R. D. (2015). Broad supernatural punishment but not moralizing high gods precede the evolution of political complexity in Austronesia. Proceedings of the Royal Society of London B: Biological Sciences, 282, 20142556.

Wilson, D. S. (2002). Darwin's cathedral: Evolution, religion, and the nature of society. University of Chicago Press.

Wright, R. (2009). The evolution of God. Little, Brown. 